\section{ALL-DIGITAL PHASE LOCKED LOOP (ADPLL) TOPOLOGIES FOR RFID SYSTEM APPLICATION: A REVIEW}

\author{
S. N. Ishaka, J. Sampe ${ }^{*}$, Z. Yusoffb, M. Faseehuddinc
}

alnstitute of Microengineering and Nanoelectronics, Universiti Kebangsaan Malaysia (UKM), 43600 Bangi, Selangor, Malaysia bFaculty of Engineering, Multimedia University, Jalan Multimedia, 63100 Cyberjaya, Selangor, Malaysia

cDepartment of Electronics \& Telecommunication, Symbiosis Institute of Technology, Symbiosis International [Deemed University], Lavale, Pune, Maharashtra 412115, India
Article history

Received

3 June 2021

Received in revised form

1 November 2021

Accepted

9 November 2021

Published Online

20 December 2021

*Corresponding author jahariah@ukm.edu.my

\section{Graphical abstract}

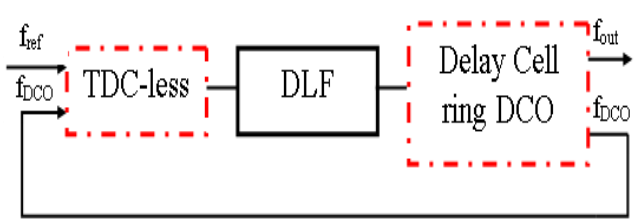

\begin{abstract}
An all-digital phase locked loop (ADPLL)-based local oscillator (LO) of RF transceiver application such as radio-frequency identification (RFID) system has gained popularity by accessing the benefits in complementary metaloxide semiconductor (CMOS) process technology. This paper reviews some state-of-art of the ADPLL structures based on their applications and analyses its major implementation block, which is the digital-controlled oscillator (DCO). The DCO is evaluated based on its CMOS scaling and its performance in ADPLL, such as the power consumption, the chip area, the frequency range, the supply voltage, and the phase noise. Based on the review, the reduction in CMOS scaling decreases the transistor size in ADPLL design which leads to a smaller area and a low power dissipation. The combination of the time-todigital (TDC) and the digital-to-time converter (DTC) that is used as the phasefrequency detector (PFD) in ADPLL is proposed to reduce the power and phase noise performance due to their high linearity design. The delay cell oscillator is found to consume more power at higher operating frequency, but it has an advantage of having less complexity and consuming less power and area in the circuit compared to the LC tank oscillator. For future work, it is recommended that an ADPLL-based LO of RFID transceiver with lowest voltage supply implementation is chosen and the use of the TDC-less as the PFD is selected due to its small area. While for the DCO, the delay cell will be designed due to its simpler implementation and occupy small area.
\end{abstract}

Keywords: All-digital, phase-locked loop, digital-controlled oscillator, radiofrequency identification, delay cell

\begin{abstract}
Abstrak
Fasa gelung terkunci semua-digit (ADPLL) berasaskan pengayun tempatan (LO) bagi aplikasi pemancar-penerima RF seperti sistem pengenalpastian frekuensi radio (RFID) telah mendapat populariti dengan mendapat faedah dalam teknologi proses semikonduktor oksida-logam pelengkap (CMOS). Kerja ini mempersembah kaijan semula mengenai struktur ADPLL berdasarkan aplikasinya dan analisis mengenai perlaksanaan blok utama iaitu topologi reka bentuk pengayun terkawal digit (DCO) yang dinilai berdasarkan penskalaan CMOSnya dan prestasinya dalam ADPLL, seperti penggunaan kuasa, kawasan cip, julat frekuensi, voltan bekalan, dan hingar fasa. Berdasarkan tinjauan, pengurangan penskalaan CMOS mengurangkan saiz transistor dalam reka bentuk ADPLL yang menghasilkan kawasan yang lebih
\end{abstract}


kecil dan pelesapan kuasa rendah. Kombinasi antara penukar masa-ke-digit (TDC) dan penukar digit-ke-masa (DTC) yang digunakan sebagai pengesan frekuensi-fasa (PFD) dalam ADPLL dicadangkan untuk mengurangkan kuasa dan prestasi hingar fasa kerana reka bentuk kelelurusannya yang tinggi. Pengayun sel lengah didapati menggunakan lebih banyak kuasa pada frekuensi operasi yang lebih tinggi, tetapi kebaikannya adalah strukturnya yang ringkas, kurang menggunakan kuasa dan menempati kawasan yang kecil berbanding dengan penggunaan pengayun tangki LC. Untuk kajian di masa depan, LO berasaskan ADPLL pemancar-penerima RFID dengan pelaksanaan bekalan voltan terendah adalah dipilih dan penggunaan kurang-TDC sebagai PFD dipilih kerana kawasannya yang kecil. Sementara untuk DCO, sel lengah akan direkabentuk kerana pelaksanaannya lebih mudah dan menempati kawasan yang kecil.

Kata kunci: semua-digit, fasa gelung terkunci, pengayun digit terkawal, pengenalpastian radio-frekuensi, sel lengah

(c) 2022 Penerbit UTM Press. All rights reserved

\subsection{INTRODUCTION}

Over the last few years, the interest in Radio Frequency Identification (RFID) system in research and industry fields have been developed and extensively used in healthcare and biomedical field [1]-[3], environment and building smart monitoring [4], tracking and localizing system [5]-[7], ecommerce management system [8], card management system [9], payment transaction [10] and other applications. This RFID technology system is a replacement of the conventional bar-code identification owing to its advantages such as realtime identification of a number of objects [11]. Figure 1 depicts a general RFID system that consists of three modules: a reader, a tag, and a host unit (computer). The system's intent is to transfer identification data/information between the reader and the tag through the RF transceiver in order to perform specific applications based on the data stored in the tag [12].

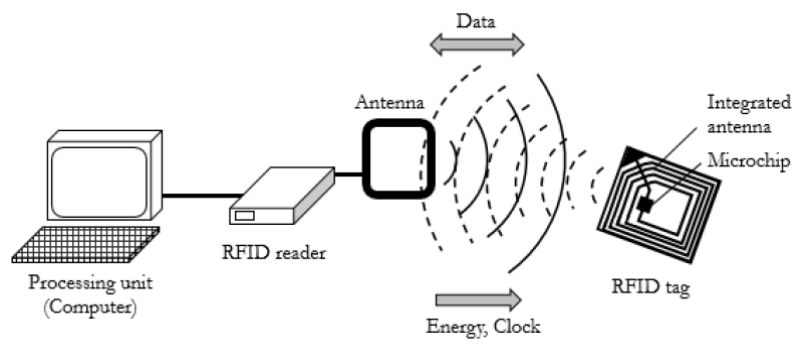

Figure 1 RFID System [12]

To date, the reported operating frequencies for RFID system are at $13.56 \mathrm{MHz}$ of High Frequency (HF) communication band [13], the Ultra High Frequency (UHF) communication band that operates between 860 to $960 \mathrm{MHz}$ [14], at $2.4 \mathrm{GHz}$ [15], and $5.8 \mathrm{GHz}$ for satellite application [16]. Each operating frequency is developed based on their suitable applications. Subsequently, current development of the RFID system is aiming for a low power device and a better data communication transfer. For examples, T. Norliza et al. designed an energy harvesting circuit in [12] by using hybrid input sources of energy to address the limitation of semi-active RFID tag lifespan issue due to the battery required to power the circuitries and J. Sampe et al. in [17] introduced a new technique of fast detection for the RFID system. Due to the advancement of the complementary metal-oxide semiconductor (CMOS) technology process, Christian et al. in [18] developed transceiver frontend chip for the passive RFID tag in industrial, scientific and medical (ISM) band while maintaining the power consumption performance. In the transceiver, the phase-locked loop (PLL) is an essential block for the local oscillator to generate frequency tuning range and normally the PLL comprises of a phase detector, a filter, and a voltage-controlled oscillator (VCO). However, with the advancement of CMOS technology process, the conventional PLL is no longer able to fulfill the requirement of the advanced transceiver [19]. Instead of a conventional mixedsignal PLL, all-digital format is proposed by research works in [20], [21] into the PLL in order to increase the performances of the local oscillator for the transceiver in terms of a low power consumption, an improved phase noise performance, a smaller chip area and have a low cost. Hence, this work reviews on a state-of-art of the all-digital phase locked loop (ADPLL) and its crucial block, which are phase frequency detector (PFD) and digital-controlled oscillator (DCO) scheme that will be compatible for future RFID system.

\subsection{ALL-DIGITAL PHASE LOCKED LOOP STATE-OF-ART}

Some RFID transceivers are built-in with the conventional PLL oscillator as reported in [18], [22], [23]. ADPLL has become popular among the researchers due to its advantages as compared to the analog counterpart such as the low power consumption and its smaller size. Other than the fast locking advantage, ADPLL is also easy to design and 
implement, has increased stability, and has a better jitter performance [24] over the conventional PLL. ADPLL's main block configuration is similar to the conventional PLL, but its circuitry is purely in the digital format. The digital phase detector or the timeto-digital converter (TDC), the digital filter and the digital-controlled oscillator (DCO) are part of the ADPLL instead of the analog phase detector, the analog filter and the VCO that part of the conventional PLL's building block. In this part, the state-of-art of the current ADPLL will be reviewed based on the suggested application and its crucial blocks will be investigated.

An early modified ADPLL architecture was proposed by Motorola in 1995 [25]. They found that the half digital PLL (DPLL) needs longer time to lock the phase and the frequency. Besides, the manufacturing of the resistor and capacitor (RC) values in the LPF of the DPLL is very challenging. Hence, an ADPLL frequency synthesizer in [24] is designed to reduce the lock time. In 2005, R.B. Staszewski et al. designed the first ADPLL frequency synthesizer [26] for GSM/EDGE transceiver of the mobile phone and achieved a better phase noise performance as compared to their previous ADPLL work for Bluetooth as reported in [27]. Not only a good frequency-synthesizer was used, ADPLL had also provided a better performance in the microprocessors as its clock generation [24], [28].

C. Chung et al. in [29] proposed the ADPLL design for smart sensing applications by introducing two mode of operations of supply voltage to reduce voltage headroom issue and frequency estimation algorithm technique at cyclic TDC-embedded DCO block. This is to optimize the efficiency process of energy in various modes. The proposed ADPLL in this work is be able to compute the DCO control code with high accuracy and achieved fast settling time. With the energy-efficient performance, the proposed ADPLL consumes less power, and it is suitable for battery-powered system. C. W. Chang et al. in [30] used dynamic voltage for the power management unit (PMU) block in their ADPLL design. The PMU block is be able to reduce up to $39 \%$ of the power consumption of the circuit with minor PMU overhead. However, the proposed ADPLL only suitable for nearthreshold operations. Meanwhile, F. Kuo et al. [31] proposed an ultra-low-voltage ADPLL that is powered from a single $0.5 \mathrm{~V}$ supply voltage with a dc-dc converter that will double the supply. The DCO is connected directly to the single supply, while the double value of supply voltage will be connected to other digital circuitries.

Y. H. Tu et al. in [32] introduced a multi-phase scheme at the TDC and the DCO blocks in the ADPLL design. The multi-phase outputs are reused in a sampled clock of TDC, which can reduce occupied area. As the results, high operational frequencies are achieved by the proposed multi-phase DCO, while high timing resolution is obtained by the proposed multi-phase TDC. J. Bae et al. in [33] proposed an
ADPLL design using a low supply voltage and includes the combination of a PFD and a controller loop topology to control the phase and frequency to achieve a stable output. Meanwhile the adopted delta-sigma modulator with a DCO is used to achieve high frequency resolution and a small number of capacitors. The phase selector block is designed after the $\mathrm{DCO}$ block which reduces the phase error and resulted faster settling time. Moreover, low phase noise performance in the proposed ADPLL is realized by a resistive biasing technique and weak-inversion operation. Y. Ho and C. Yao in [34] introduced a phase-frequency error compensation technique in their designed ADPLL. The compensation technique of the phase error and frequency error in the ADPLL are working simultaneously and fulfilled the fast-acquisition requirement.

\subsection{Digital Phase Frequency Detector (DPFD)}

The digital phase frequency detector (DPFD) is the first block in an ADPLL that measures the difference of the phase and the frequency of the input signal, which is the reference signal and the output signal of the DCO. One of the most popular methodology to build a DPFD is using time-to-digital converter (TDC). The advantage of the TDC is to measure the time difference between the two separate signals with good resolution [35]. Y. Balcioglu and G. Dundar [36] presented a new quantization noise suppression method to improve the noise performance in the TDC in order to achieve superior jitter performance. In this design, good jitter performance of the ADPLL is achieved and the occupied area is small. However, the proposed ADPLL is still consumed a large power. The Intel researchers consists of R. Levinger et al. [37] presented the ultra-low power ADPLL by interpolating the TDC block. The TDC integration is introduced to support the performance of the LC DCO bank.

However, some researchers found that the full range of TDC used may degrade the performance of the ADPLL due to its power hungry. T. Siriburanon et al. in [38] used the ADC with the voltage-domain digitization instead of a full range of TDC that produced a limited resolution of the phase digitization and dissipated a large power. While in [39], Y. Wu et al. maintained the used of the TDC, but the circuit is assisted by the addition of DTC in order to achieve a low in-band phase noise. This study is supported by $\mathrm{H}$. Liu et al. in [40] which their DTCassisted TDC achieved a high linearity phase detector. Besides that, the DTC-assisted TDC resulted in a high-resolution noise shaping. The other research that supported the DTC-TDC based is in [41] by $N$. Yan et al. that used phase prediction algorithm to minimize the detection range of the TDC. The $\Sigma \Delta$ dither block is designed to improve the nonlinearity of the DTC.

A few techniques are introduced to improve the power consumption of the ADPLL. As an example, a 
reduction of a full-ranged TDC has been proposed in [42] by using the fractional TDC architecture. The proposed design consumed less power and occupied smaller area. J. K. Sahani et al. in [43] proposed the DPFD architecture which includes the high resolution TDC by calibrating the processvoltage-and-temperature (PVT) variation to enhance the jitter performance. The dynamic bang-bang PFD is used to improve the locking time performance. The use of the TDC with bang-bang PFD has also been used in [44] where the design achieved a higher resolution performance and a faster locking time. Table 1 shows the summary of the advantages and the disadvantages for the PFD design topologies in various ADPLL.

Table 1 The phase-frequency detector in various ADPLL

\begin{tabular}{|c|c|c|c|}
\hline Ref & PFD & Advantages & Disadvantages \\
\hline$[37]$ & Full-TDC & - High resolution & - High power \\
\hline [38] & ADC & $\begin{array}{l}\text {-High resolution } \\
\text { - Low power }\end{array}$ & \\
\hline $\begin{array}{l}{[39],} \\
{[40],} \\
{[41]}\end{array}$ & $\begin{array}{l}\text { TDC with } \\
\text { DTC }\end{array}$ & $\begin{array}{l}\text { - Low in-band phase } \\
\text { noise } \\
\text { •High linearity } \\
\text { •High resolution noise } \\
\text { shaping }\end{array}$ & $\begin{array}{l}\text { - More area } \\
\text { needed }\end{array}$ \\
\hline$[42]$ & TDC-less & $\begin{array}{l}\text {-Low power } \\
\text { consumption } \\
\text {-Save area } \\
\text { consumption }\end{array}$ & $\begin{array}{l}\text { - Resolution } \\
\text { may } \\
\text { degrade }\end{array}$ \\
\hline [43] & $\begin{array}{l}\text { TDC with } \\
\text { bang- } \\
\text { bang PFD }\end{array}$ & $\begin{array}{l}\text {-High resolution } \\
\text { - Low jitter and low } \\
\text { power } \\
\text {-Fast locking time } \\
\text {-PVT robust }\end{array}$ & $\begin{array}{l}\text { - More area } \\
\text { needed }\end{array}$ \\
\hline
\end{tabular}

\subsection{Digital Loop Filter (DLF)}

Besides the phase-frequency detector block, the digital loop filter (DLF) is another challenging block to design in the ADPLL. Researchers W. Yang et al. in [45] proposed the phase self-alignment mechanism and the dynamic loop gain control in their digital loop filter (DLF) of the ADPLL. The phase selfalignment is proposed to resolve the overdamping caused by a large loop gain controller $\left(K_{1}\right)$ in the DLF and to reduce the locking time of the ADPLL. The proposed design has reduced the locking time by $91 \%$ compared with conventional PLL. This design exhibited a superior performance in terms of locking time and the jitter performance, and suitable for the sub-GHz Internet-of-Things (IOT) band applications. M. Sayadi and E. Farshidi [46] introduced a new approach for the loop filter design by proposing a model predictive control (MPC) method. The proposed method achieved a faster transient response and the model can be designed to eliminate the noise sources that come from the oscillator without degrading the phase noise performance.

\subsection{Digital-controlled Oscillator (DCO)}

Furthermore, the design of DCO is one of the current interests among the researchers. As in the conventional PLL, the VCO is the heart and most critical design part. It is because the VCO's output frequency has a direct impact on the timing accuracy where phase alignment is required and the signal-to-noise ratio (SNR) frequency translation is performed [47]. This output frequency will affect the jitter and phase noise performance in the design as well as the power consumption in the transceiver. While in ADPLL, the DCO is used to perform the digital-to-frequency conversion [26]. The DCO, which was first reported in [48], designed for the RF wireless applications. The DCO lies at the heart of the ADPLLbased frequency synthesizer that acts as a local oscillator for the transmitter and the receiver. The DCO deliberately avoids any analog tuning controls. Similar to the $\mathrm{VCO}$ in the PLL, the DCO is the most power hungry circuit in the ADPLL [49].

\subsubsection{LC-DCO}

The basic of the LC-based DCO depicts as in Figure 2 , which is comprised of the voltage supply, the LC tank, a pair of CMOS cross-coupled transistors, the varactors, the constant bias transistor, and a pair of inverters. The optimization of the phase noise performance can be done by putting an LC filter in parallel with the constant bias transistor [50] in order to transfer the noise signal to the ground. The use of this method needs an additional inductor to increase the impedance of the constant bias transistor at the oscillation frequency. The drawback of this method that it will increase the chip size and it will affect the inductor in working at the resonant frequencies. To solve the problem, the work in [51] added two MOS transistor at the top constant bias to optimise the phase noise performance. These two MOS transistors imposed the triode mode to the DCO, and the flicker noise has reduced as compared to the use of the normal transistor bias, which only operated in one mode. While in [52], the inductor-less technique is used in the LC tank, which resulted in less area consumption. 


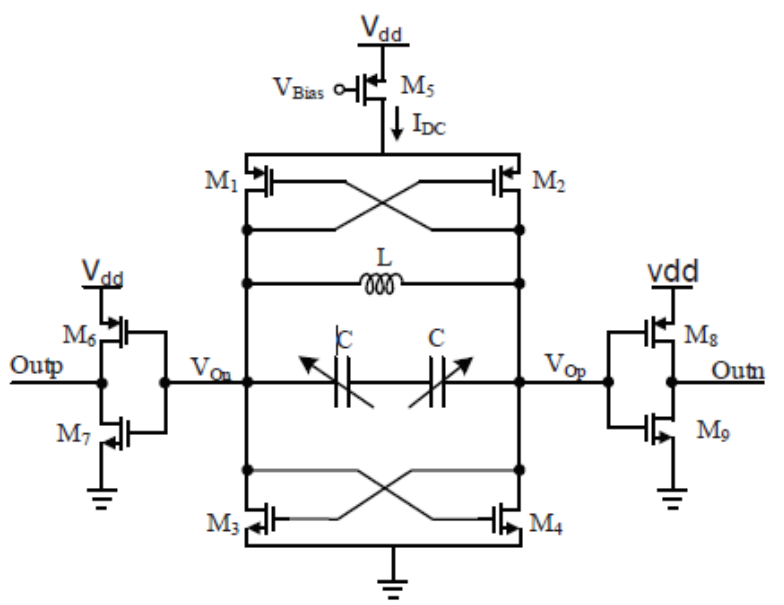

Figure 2 LC-DCO schematic [51]

Power consumption can be improved if the LC factor is increased. Y. Wang et al. in [53] presented an ultra-low power 1-bit DCO with a high quality factor capacitor and inductor to minimize the loss in the LC tank. In this case, the value of the capacitor and inductor must be well designed. However, the increase of the LC factor can increase the transistor size that leads to a large area. Other than that, the decrease of the voltage supply may also help the performance of the power consumption in the DCO. Work in M. Moreira et al. [54] proposed a low power cross-coupled LC-tank DCO by reducing the voltage supply down to $0.4 \mathrm{~V}$ in order to restrict the power consumption. The technique of downsizing the voltage supply is a critical challenge it may degrade the performance of the phase noise. To solve this problem, the transistor would be designed with an increased width size which to reduce the flicker noise. Unfortunately, the increase in the width of the transistor will occupy large area.

\subsubsection{DCO (DAC+DCO)}

Based on the literature, one approach in the DCO design is by the combination of the digital-to-analog converter (DAC) and the traditional VCO. Two separate designs of the DAC and the VCO are needed to ensure that the performance of the DCO can achieve flexibility and stability. The advantage of this DCO is straight-forward, which the usage of the $D A C$ is to convert the phase error in digital format to the voltage form and drive the varactor in LC VCO to change the frequency. However, the big challenge of this approach is the head room issue due to the DAC works in the voltage domain. To overcome this problem, L. Lou et al. has proposed a continuous wide tuning range and a low phase noise of flexible DCO in [55].

E. Szopos et al. presented in [56] cascaded the DAC and the VCO to build a DCO block. The frequency lock time and jitter performance (two conflicting metrics) are mainly affected by the DCO resolution; thus a trade-off compromise should be sought when choosing the resolution. The jitter versus the resolution characteristics is an aid for the designer to choose the proper resolution for example, 0.1 ps jitter needs to use 18-bit DCO.

\subsubsection{MOS Varactor}

In the past work, the capacitor used in the LC tank oscillator of the VCO is a passive type. With the advancement of the CMOS process technology, the MOS varactor or the active capacitor are widely chosen due to its low power consumption and it occupied a small size area. The MOS varactor is varied by the control voltage. As the graph shown in the Figure 3 , the increase of the control voltage will decrease the capacitance of the MOS varactor. Due to that, the MOS varactor is suitable for tuning in the LC-VCO circuit. The MOS varactor type, either NMOS or PMOS, is selected based on their design requirement. Based on P. Solanki et al. in [57] the NMOS varactor is chosen due to its weighting characteristic in terms of the small area, the wide tuning range and the low power consumption. However, according to L. Lou et al. [55] and M. S. Sadr et al. in [51], the NMOS varactor has high sensitivity to the noise due to the fabrication process. Hence, the PMOS varactor is highly recommended for a better noise performance and has less parasitic capacitance.

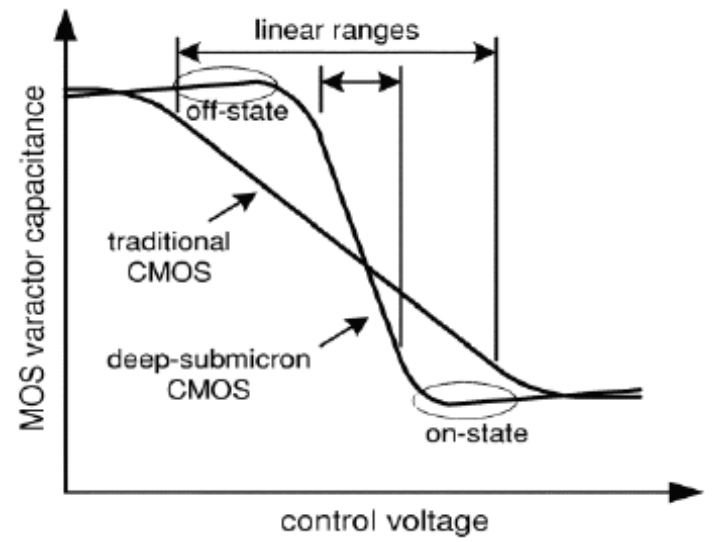

Figure 3 MOS varactor capacitance characteristics in CMOS [51]

\subsubsection{Inverter or Delay Cell DCO}

Besides the LC-tank approach, the delay cell with several stages can be used as the DCO. Typically, the inverter-based DCO is comprised of the PMOS and the NMOS transistors for each stage. Figure 4 below shows the conventional DCO with several stages or can be called as the ring DCO. The inverter introduces short time delay for each stage or delay cell and the needs of the inverter stage is depending on the design requirement [58]. 


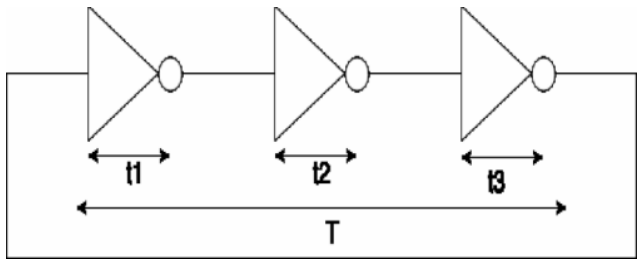

Figure 4 The conventional of DCO ring topology [58]

S. Dabas and M. Kumar in [59] added the NMOS transistors as the switching network which control the DCO bit and placed them in between the supply voltage and the CMOS inverter delay stage. The resistance posed by the switching network and the inverter offered by each stage is determined by the input vector applied which in turn determines the DCO output oscillation frequency. From this study, the use of the inverter stage will affect the performance of the power consumption and the output frequency range.

S. Pahlavan et al. in [60] introduced a differential ring oscillator with a delay element for the DCO that can work at two different frequency bands and is powered by the digital selection mode. The design achieved a lower and a higher power consumption at a lower and a higher frequency band respectively. Thus, this proposed design may only be suitable for low frequency multi-standard applications.

C. Yuan et al. in [61] presented a 2-stage differential ring oscillator with an inverter-based delay cells, a resistor-triode load and a weak cross-coupled latch cell to cancel the power supply noise. The proposed technique does not require the analog design and does not reduce voltage headroom. This technique minimally affects the phase noise only at large frequency offset, where its contribution to the integrated jitter is minimal. A proof-of-concept prototype DCO can withstand $50 \mathrm{mVpp}$ excursions on the supply with less than $10 \%$ frequency pushing.

D. Sheng et al. in [62] presented a delay cell with the NAND gate approach as shown in Figure 5. The proposed multi-stage design is not only occupied a smaller silicon area, but also has a higher delay resolution. Furthermore, because the proposed design can migrate to a different process easily, it can decrease the design turn-around-time and the design effort significantly. As a result, it is very suitable for system-level integration and System-on-Chip (SoC) applications.

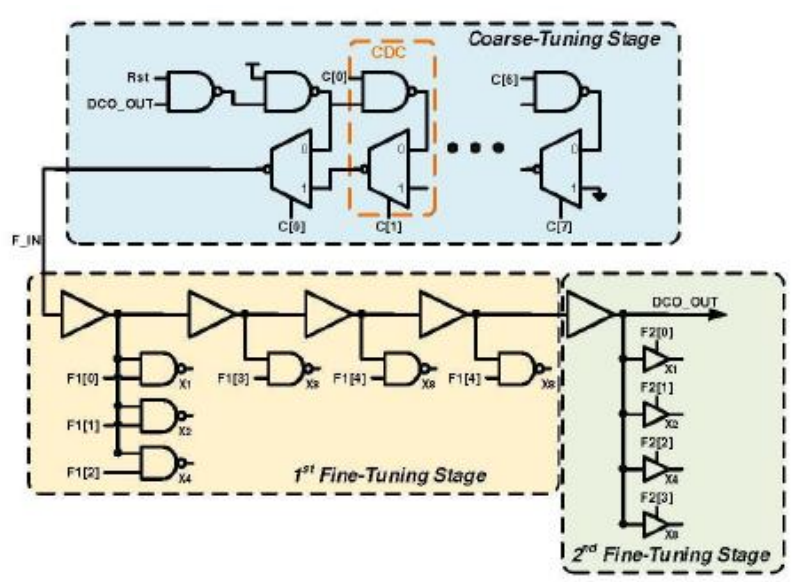

Figure 5 NAND gate approach of delay cell [62]

P. Bisiaux et al. in [63] presented the five stages differential amplifiers as the inverters or the delay cells and a bias circuit with a stable voltage output as shown as Figure 6. This design preferred delay cells based on differential current logic instead of voltage logic to minimize power supply variation noise. The hybrid of the binary to thermometer code block and the frequency control block (FCB) in this proposed design has achieved a high resolution and has minimized the mismatch effect.

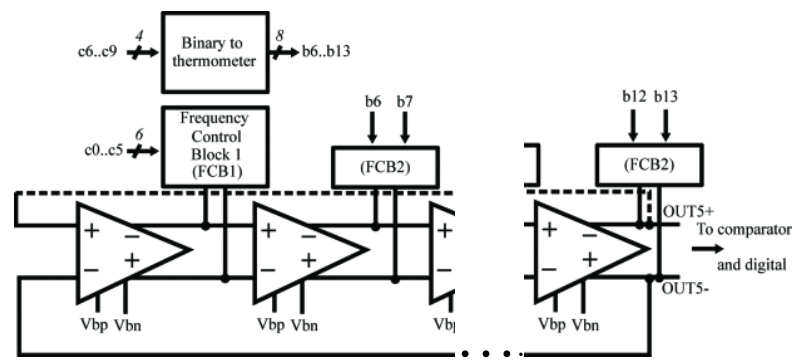

Figure 6 The five stages differential amplifiers delay cells [63]

S. Selvaraj et al. in [64] proposed a DCO by using four delay cells with a cross-coupled inverter architecture to improve the phase noise and jitter performance. The DCO composed of the combination of the DAC and the ring oscillator along with the output differential buffer as shown as Figure 7. The proposed design achieved high stability, high efficiency and, wide operating frequency range performance, and also the ability to generate multiphase signals. The state-of-art of the DCO scheme is summarized as shown as Table 2 by differentiate the advantages and its design challenge. 


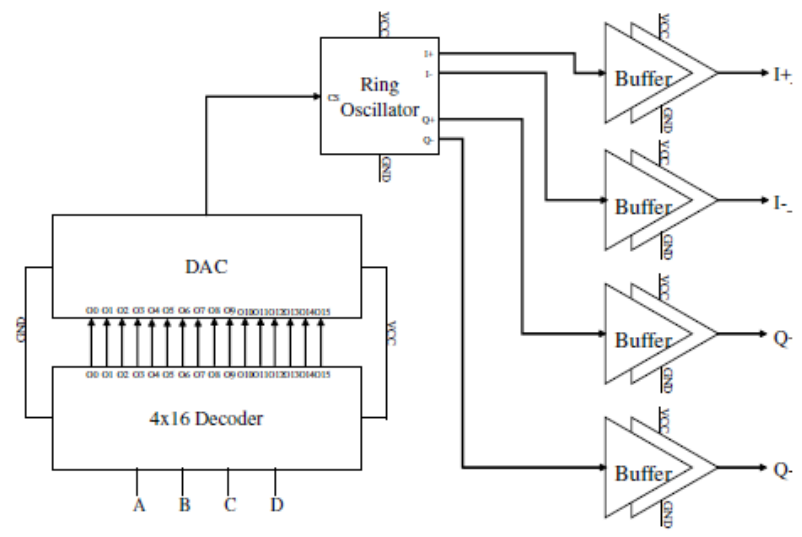

Figure $7 \mathrm{~S}$. Selvaraj et al. proposed the DCO design in [64]

\subsection{DISCUSSION}

Generally, an ADPLL consists of a phase detector, a loop filter and a controlled oscillator with all-digital format. Recently, various designs are approached by numerous researchers in order to improve performance of the local oscillator in terms power consumption, phase noise, chip area, and cost. Based on the reviewed literature, the CMOS scaling is the most challenging design stage for the local oscillator because the circuit has to minimize to nanometres size. The component has to be designed meticulously in order to maintain the local oscillator performance.

The advantages and the applications of the state-of-art ADPLL are shown in Table 3. The reported ADPLLs are conducted from 2016 to 2020. From the Table 3, there are two major blocks that have been approached, which is the PFD and the DCO blocks. The use of the TDC as the phase detector is gaining popularity due to its simpler design and easier implementation. However, some researchers found that the full range TDC used can cause higher power consumption. The combination of the DTC with the TDC is proposed to reduce the power consumption and to increase the phase noise performance due to their high linearity in the design. The other approach of PFD design, the TDC-less such as in [42] and the combination of bang-bang PFD with TDC such as in [43] are quite impressive since both approaches offered less power consumption and smaller occupied area.

Table 2 The summary of the DCO advantages and challenges

\begin{tabular}{|c|c|c|c|}
\hline Ref & $\begin{array}{l}\text { DCO } \\
\text { state- } \\
\text { of-art }\end{array}$ & Advantages & Challenges \\
\hline $\begin{array}{l}{[50]} \\
{[51]} \\
{[52]} \\
{[53]} \\
{[54]}\end{array}$ & $\begin{array}{l}\mathrm{LC} \\
\mathrm{DCO}\end{array}$ & $\begin{array}{l}\text { - Low power } \\
\text { consumption. } \\
\text { - Good phase noise } \\
\text { performance. }\end{array}$ & $\begin{array}{l}\text { - Large LC factor } \\
\text { and transistor size } \\
\text { increase chip size. } \\
\text { - Proper value of } \\
\text { LC is needed to } \\
\text { design. } \\
\text { - Difficult to design. }\end{array}$ \\
\hline $\begin{array}{l}{[55]} \\
{[56]}\end{array}$ & $\begin{array}{l}\text { DAC } \\
\text { with LC } \\
\text { VCO }\end{array}$ & $\begin{array}{l}\text { - Straight forward } \\
\text { flow design. } \\
\text { - Low phase noise } \\
\text { - Wide tuning range }\end{array}$ & $\begin{array}{l}\text { - Head room issue } \\
\text { - Need proper } \\
\text { parameter on } \\
\text { resolution design }\end{array}$ \\
\hline $\begin{array}{l}{[51]} \\
{[55]} \\
{[57]} \\
{[65]}\end{array}$ & $\begin{array}{l}\text { MOS } \\
\text { Varact } \\
\text { or }\end{array}$ & $\begin{array}{l}\text { - Low power } \\
\text { consumption } \\
\text { - Occupy small area. } \\
\text { - Suitable for LC-VCO } \\
\text { circuit and } \\
\text { inverter/delay cell. }\end{array}$ & $\begin{array}{l}\text { - High sensitivity to } \\
\text { the noise. }\end{array}$ \\
\hline $\begin{array}{l}{[59]} \\
{[61]} \\
{[62]} \\
{[63]} \\
6 \\
{[64]}\end{array}$ & $\begin{array}{l}\text { Inverter } \\
\text { or } \\
\text { delay } \\
\text { cell }\end{array}$ & $\begin{array}{l}\text { - Decrease design } \\
\text { effort } \\
\text { - High resolution } \\
\text { - Minimize mismatch } \\
\text { effect } \\
\text { - High stability and } \\
\text { high efficiency } \\
\text { - Wide frequency } \\
\text { tuning }\end{array}$ & $\begin{array}{l}\text { - High power } \\
\text { consumption at } \\
\text { high operating } \\
\text { frequency }\end{array}$ \\
\hline
\end{tabular}

Table 3 ADPLL review

\begin{tabular}{|c|c|c|c|}
\hline $\begin{array}{l}\text { Year, } \\
\text { Ref }\end{array}$ & ADPLL state-of-art & Achievement & Application \\
\hline $2016,[29]$ & $\begin{array}{l}\text { Dynamic supply voltage } \\
\text { Frequency estimation TDC- } \\
\text { embedded DCO }\end{array}$ & $\begin{array}{ll}\text { - } & \text { Fast settling time } \\
\text { - } & \text { High energy efficiency } \\
\text { - } & \text { Low power consumption } \\
\text { - } & \text { Small chip area }\end{array}$ & $\begin{array}{l}\text { Battery-powered smart sensing } \\
\text { device }\end{array}$ \\
\hline 2016, [30] & Dynamic supply voltage & $\begin{array}{ll}\text { - } & \text { Fast lock-in time } \\
\text { - } & \text { High efficiency } \\
\text { - } & \text { Low power consumption } \\
\text { - } & \text { Small chip area }\end{array}$ & Low-voltage system \\
\hline $2016,[32]$ & $\begin{array}{l}\text { Multi-phase scheme technique at } \\
\text { TDC and DCO }\end{array}$ & $\begin{array}{l}\text { - Save area } \\
\text { - Low power consumption at high } \\
\text { frequency }\end{array}$ & Low-voltage system \\
\hline
\end{tabular}




\begin{tabular}{|c|c|c|c|}
\hline $\begin{array}{l}\text { Year, } \\
\text { Ref }\end{array}$ & ADPLL state-of-art & Achievement & Application \\
\hline 2016, [33] & $\begin{array}{l}\text { The combinational of PFD with } \\
\text { controller. } \\
\text { Delta-sigma modulator DCO } \\
\text { Phase interpolator as filter }\end{array}$ & $\begin{array}{ll}\text { - } & \text { Low power consumption } \\
\text { - } & \text { High stability } \\
\text { - } & \text { High frequency resolution } \\
\text { - } & \text { Fast settling time } \\
\text { - } & \text { Low phase noise }\end{array}$ & $\begin{array}{l}\text { Medical implantable } \\
\text { transceiver (MICS) }\end{array}$ \\
\hline $2016,[34]$ & $\begin{array}{l}\text { Phase-frequency-error } \\
\text { compensation technique }\end{array}$ & $\begin{array}{l}\text { - Improved jitter performance } \\
\text { - } \quad \text { Fast acquisition time }\end{array}$ & Dynamic frequency scaling \\
\hline 2016, [38] & ADC used instead of TDC & $\begin{array}{l}\text { - Low power consumption. } \\
\text { - High resolution of phase digitization }\end{array}$ & Internet-of-Things (loTs) device \\
\hline $2016,[46]$ & $\begin{array}{l}\text { Model predictive control (MPC) } \\
\text { loop filter }\end{array}$ & - Fast transient response & Wireless system \\
\hline $2017,[31]$ & Switched-capacitor doubler & $\begin{array}{l}\text { - Low voltage supply is needed. } \\
\text { - Low power device }\end{array}$ & Blvetooth low energy \\
\hline 2017, [39] & DTC-assisted TDC & $\begin{array}{ll}\text { - } & \text { High resolution noise shaping } \\
\text { - } & \text { High linearity } \\
\text { - } & \text { Low band noise }\end{array}$ & RF system-on-chip (SoC) \\
\hline $2018,[40]$ & DTC-assisted TDC & $\begin{array}{l}\text { - } \quad \text { Occupied small area } \\
\text { - } \quad \text { Good jitter performance } \\
\text { - } \quad \text { Low power operation }\end{array}$ & BLE, Zigbee. And WPAN/WBAN \\
\hline 2019, [37] & $\begin{array}{l}\text { Interpolating TDC and LC tank } \\
\text { DCO }\end{array}$ & $\begin{array}{l}\text { - } \quad \text { Ultra-low power } \\
\text { - } \quad \text { Occupied small area } \\
\text { - } \quad \text { Good jitter performance }\end{array}$ & 802.1 lac standard \\
\hline $2019,[41]$ & DTC-assisted TDC & $\begin{array}{l}\text { - } \quad \text { Good in-band phase noise } \\
\text { - } \quad \text { Improved jitter performance } \\
\text { - } \quad \text { Reduced locking time }\end{array}$ & Narrow-band loT \\
\hline $2019,[42]$ & $\begin{array}{l}\text { Capacitively boosted differential } \\
\text { ring oscillator DCO, TDC-less }\end{array}$ & $\begin{array}{l}\text { - Ultra-low area } \\
\text { - Low power consumption }\end{array}$ & Biomedical implant SoC \\
\hline 2020, [43] & $\begin{array}{l}\text { Foreground LMS algorithm-based } \\
\text { calibration method }\end{array}$ & $\begin{array}{ll}\text { - } & \text { Low power } \\
\text { - } & \text { Low jitter } \\
\text { - } & \text { PVT robust } \\
\end{array}$ & $\begin{array}{l}\text { SoC and battery-powered } \\
\text { high-speed applications }\end{array}$ \\
\hline
\end{tabular}

The DCO design is more crucial as compared to the phase detector because the DCO is the heart of the ADPLL system. Table 4 shows a list of the DCO cores of the ADPLL and their performance reported from year 2016 to 2020. Commonly, there are two types of the DCO approach: LC tank and delay cell based. The selection of DCO type is based on the desired performances. From Table 4, the performance of the DCO is evaluated by the CMOS scaling technology process, the frequency tuning range, the supply voltage, the power consumption, the figure-of-merit (FoM) and the occupied area. Based on the reviewed, LC tank oscillator is widely used by many researchers as compared to the delay cell element because of its better phase noise performance. Nevertheless, the frequency tuning range of LC tank is limited, and meticulous design is needed. Research works in [51] and other LC tank work need some specific value of LC in order to design the LC tank based on the desired frequency tuning range. This means that the LC tank oscillator is not flexible as changing the oscillation frequency will require redesigning the circuit again. Opposite to the delay cell based DCO, which can produce large frequency tuning and it is easy to design but it consumes more power at high frequency range. In $180 \mathrm{~nm}$ CMOS technology at low frequency range, LC tank DCO work in [57] offered almost $30 \%$ better power consumption when compared to delay cell work in [60]. However, the time to design the delay cell unit is saved, which decreases the design complexity compared to LC tank. D. Sheng et al. in [62] has been presented a multi-stage delay cell which is not only occupied $0.0018 \mathrm{~mm}^{2}$ die area, but also has a higher delay resolution. In addition, the proposed design can be moved to a different process easily, as well as decreases the design time and the design complexity significantly.

In terms of area, the LC oscillator occupied more area compared to delay cell oscillator. We can see 
from the Table 4 , in $65 \mathrm{~nm}$ CMOS technology, the delay cell-based DCO used in work [64] offered very small occupied area when compared to LC tankbased DCO used in [50]. Work research in [54] offered the lowest voltage supply for DCO circuit and followed by [53] and [61] which used supply less than
$1 \mathrm{~V}$. The voltage supply is another design challenge because the low supply can reduce the power consumption of the device. Energy harvester circuit is another option to power up the local oscillator. Hence, the limited power supply can be saved up more.

Table 4 DCO review

\begin{tabular}{|c|c|c|c|c|c|c|c|c|}
\hline Year, Ref & DCO core & $\begin{array}{l}\text { CMOS } \\
(\mathrm{nm})\end{array}$ & $\begin{array}{l}\text { Freq. Range. } \\
\text { (GHz) }\end{array}$ & Supply (V) & Power (mW) & FoM (dBc/Hz) & $\begin{array}{l}\text { Die } \\
\left(\mathrm{mm}^{2}\right)\end{array}$ & Area \\
\hline $2016,[51]$ & LC tank & 90 & $10-10.7$ & 1.2 & 4.9 & -189 & $\mathrm{n} / \mathrm{a}$ & \\
\hline $2016,[55]$ & LC tank & 65 & $13.69-15.93$ & 1.2 & 16.5 & -169.6 & $\mathrm{n} / \mathrm{a}$ & \\
\hline $2016,[60]$ & Delay cell & 180 & $1.39-1.452$ & 1.8 & 10.1 & $n / a$ & $\mathrm{n} / \mathrm{a}$ & \\
\hline $2017,[66]$ & LC tank & 28 & $39.3-42.9$ & 1.0 & 10.5 & -180 & 0.08 & \\
\hline 2018, [57] & LC tank & 180 & $2.28-2.74$ & 1.8 & 6.33 & $\mathrm{n} / \mathrm{a}$ & 0.03 & \\
\hline $2019,[50]$ & LC tank & 65 & $5.2-5.8$ & 1.2 & 2.52 & -183.77 & 0.28 & \\
\hline $2019,[52]$ & LC tank & 130 & $1.8-2.6$ & 1.1 & 5.3 & -150 & 0.003 & \\
\hline 2019, [53] & LC tank & 65 & $74.1-76.7$ & 0.75 & 3.15 & 164.62 & 0.056 & \\
\hline $2019,[54]$ & LC tank & 40 & $1.8-1.86$ & 0.4 & 0.38 & $\mathrm{n} / \mathrm{a}$ & 0.46 & \\
\hline $2019,[61]$ & Delay cell & 65 & $0.9-1.4$ & 0.85 & 2.45 & $\mathrm{n} / \mathrm{a}$ & 0.0189 & \\
\hline 2019, [67] & LC tank & 180 & $12.4-12.6$ & $\mathrm{n} / \mathrm{a}$ & $n / a$ & $\mathrm{n} / \mathrm{a}$ & $n / a$ & \\
\hline 2020, [62] & Delay cell & 180 & $0.16-0.346$ & 1.8 & 0.525 & $\mathrm{n} / \mathrm{a}$ & 0.0018 & \\
\hline 2020, [63] & Delay Cell & 28 & $1.13-1.54$ & 1.0 & 0.84 & -135.5 & 0.0056 & \\
\hline 2020, [64] & Delay cell & 65 & $1.8-2.2$ & 1.2 & 1.6 & -219.2 & 0.00037 & \\
\hline
\end{tabular}

\subsection{CONCLUSION}

An ADPLL for the RF transceiver becoming popular among researchers due to the benefits of the CMOS technology process. In this work, the state-of-art of the ADPLL is reviewed based on its performance in terms of the design configuration and its suitable application. Based on the state-of-art ADPLL, the low voltage supply has improved the power consumption performance of the application. As for the PFD, the used of the TDC-less technique can reduce the power consumption and the die area. Furthermore, the DCO design is the more critical as compared to PFD. Hence, the review had focused on the current design topologies development of the DCO based on the type of the DCO core, either the LC tank or the delay cell element, the power performance, and the die area. It is found that, the selection of the DCO type is depending on the application design requirements. The LC DCO can give lower phase noise performance, but the design is more complex. As for a simpler and easier design, the delay cell element can be adopted in the DCO. However, the design challenge of the delay cell DCO is to maintain the low power consumption at high operating frequency. The delay cell DCO also can achieve wide tuning frequency ranges as compared to the LC DCO. Thus, for the future work of the local ADPLL RFID transceiver, the low voltage supply should be considered, and the TDC-less phase detector should be adopted to achieve smaller area and lower power consumption. The delay cell should be designed for the DCO for because of its simpler implementation and it consumed smaller area while maintaining the low power consumption at high operating frequency.

\section{Acknowledgement}

This work is funded by Ministry of Education Malaysia under grant (FRGS/1/2018/TK04/UKM/02/1) and AKU254:HICoE (Fasa II) 'MEMS for Biomedical Devices (artificial kidney)'.

\section{References}

[1] Izza, S., M. Benssalah, and K. Droviche. 2021. An Enhanced Scalable and Secure RFID Authentication Protocol for WBAN within an IOT Environment. J. Inf. Secur. Appl. 58. DOI: 10.1016/j.jisa.2020.102705.

[2] Xie, S., F. Zhang, and R. Cheng. 2021. Security Enhanced RFID Authentication Protocols for Healthcare Environment. Wirel. Pers. Commun. 117(1): 71-86. DOI: 10.1007/s11277020-07042-6.

[3] Dey, S., R. Bhattacharyya, S. E. Sarma, and N. C. Karmakar. 2021. A Novel 'Smart Skin' Sensor for Chipless RFID-Based Structural Health Monitoring Applications. IEEE Internet Things J. 8(5): 3955-3971. DOI: 10.1109/JIOT.2020.3026729.

[4] Cai, M., and S. Mirrabbasi. 2021. A Self-sustained Smart Monitoring Platform for Capacitive De-lonization Cell in Wireless Sensor Network. IEEE Trans. Ind. Electron. 68(5): 4164-4172. DOI: 10.1 109/TIE.2020.2982104.

[5] Rohei, M. S., E. Salwana, N. B. A. K. Shah, and A. S. Kakar. 2021. Design and Testing of an Epidermal RFID Mechanism in a Smart Indoor Human Tracking System. IEEE Sens. J. 21 (4): 5476-5486. DOI: 10.1109/JSEN.2020.3036233. 
[6] Caldero, P., M. Gareis, and M. Vossiek. 2021. HighAccuracy 3D SAW RFID Tag Localization Using a MultiAntenna Mobile Robot Based Synthetic Aperture Approach. 2020 50th European Microwave Conference, EUMC 2020. 698-701. DOl: 10.23919/EuMC48046.2021.9338123.

[7] Motroni, A., A. Buffi, P. Nepa, and B. Tellini. 2021. SensorFusion and Tracking Method for Indoor Vehicles with LowDensity UHF-RFID Tags. IEEE Trans. Instrum. Meas. 70. DOI: 10.1 109/TIM.2020.3027926.

[8] Xu, S., J. Chen, M. Wu, and C. Zhao. 2021. E-Commerce Supply Chain Process Optimization based on Wholeprocess Sharing of Internet of Things Identification Technology. C. - Comput. Model. Eng. Sci. 126(2): 843-854. DOI: 10.32604/cmes.2021.014265.

[9] Damanik, I. A. V., R. D. Rumbara, and N. Juhana. 2020. Online Monitoring for Processes and Condition of a Machine using Smart Management Card. IOP Conference Series: Materials Science and Engineering. 980(1). DOI: 10.1088/1757-899X/980/1/012047.

[10] Vallabhuni, R. R., S. Lakshmanachari, G. Avanthi, and V. Vijay. 2020. Smart Cart Shopping System with an RFID Interface for Human Assistance. Proceedings of the 3rd International Conference on Intelligent Sustainable Systems, ICISS $2020 . \quad$ 165-169. DOI: 10.1109/ICISS49785.2020.9316102.

[11] Gope, P., O. Millwood, and N. Saxena. 2021. A Provably Secure Authentication Scheme for RFID-enabled UAV Applications. Comput. Commun. 166: 19-25. DOI: 10.1016/j.comcom.2020.11.009.

[12] Tengku Mohamad, T. N., J. Sampe, M. Islam, and D. Berhanuddin. 2017. Architecture of Micro Energy Harvesting Using Hybrid Input of RF, Thermal and Vibration for Semi- Active RFID Tag. Eng. J. 21: 183-197.

[13] Song, H.-J., S. Yoo, and H. Yoo. 2010. Implementation of HF Multi-standard RFID Transceiver for Compact Mobile Devices. 2010 IEEE International Conference of Electron Devices and Solid-State Circuits (EDSSC). 1-4. DOI: 10.1109/EDSSC.2010.5713700.

[14] Wang, K., C. Zhang, Y. Zhang, X. Ji, Y. Zhang, F. Yuan, and Y. Guo. 2016. A Monolithic UHF RFID Transceiver for Mobile UHF RFID Readers. 2016 International Conference on Integrated Circuits and Microsystems (ICICM). 154-158. DOI: 10.1109/ICAM.2016.7813583.

[15] Bhuiyan, M. A. S., M. B. I. Reaz, J. Jalil, L. F. Rahman, and T. G. Chang. 2015. A Compact Transmit/receive Switch for 2.4 GHz Reader-less Active RFID Tag Transceiver. J. Cent. South Univ. 22(2): 546-551. DOI: 10.1007/s1 1771-015-2554-2.

[16] Qi, C., J. D. Griffin, and G. D. Durgin. 2018. Low-power and Compact Microwave RFID Reader for Sensing Applications in Space. 2018 IEEE International Conference on RFID Technology \& Application (RFID-TA). 1-6. DOI: 10.1109/RFID-TA.2018.8552823.

[17] Sampe, J. and M. Othman. 2008. Fast Detection Anticollision Algorithm for RFID System Implemented On-chip. J. Appl. Sci. 8(7): 1315-1319. DOl: 10.3923/jas.2008.1315.1319.

[18] Bredendiek, C., D. A. Funke, J. Schöpfel, V. Kloubert, B. Welp, and K. Aufinger. 2018. A 61-GHz SiGe Transceiver Frontend for Energy and Data Transmission of Passive RFID Single-Chip Tags with Integrated Antennas. IEEE J. SolidState Circuits. 53(9): 2441-2453. DOI: $10.1109 /$ JSSC.2018.2843348.

[19] Bae, J., S. Radhapuram, I. Jo, T. Kihara, and T. Matsuoka. 2015. A Low-voltage Design of Controller-based ADPLL for Implantable Biomedical Devices. 2015 IEEE Biomedical Circuits and Systems Conference (BioCAS). 1-4. DOI: 10.1109/BioCAS.2015.7348405.

[20] Wang, Y., G. Wang, and W. Liu. 2011. Design and Implementation of the RF Front-end All-digital Phaselocked Loop in the UHF RFID Reader. Key Engineering Materials. 474-476. 63-68. DOl: 10.4028/www.scientific.net/KEM.474-476.63.

[21] Badal, M. T. I., M. J. Alam, M. B. I. Reaz, M. S. Bhuiyan, and
N. A. Jahan. 2019. High-resolution Time to Digital Converter in $0.13 \mu \mathrm{m}$ CMOS Process for RFID Phase Locked Loop. J. Eng. Sci. Technol. 14(4): 1776-1788.

[22] Jalil, J., M. B. I. Reaz, L. F. Rahman, and M. Marufuzzaman. 2012. Differential Ring Oscillator based voltage Control Oscillator for Readerless RFID Transponder. 2012 4th International Conference on Intelligent and Advanced Systems (ICIAS2012). 2: 807-810. DOI: 10.1109/ICIAS.2012.6306124.

[23] Akhmetov, D. B. A., S. Korotkov, and I. A. Rumyancev. 2018. 2.4-2.5 GHz Fractional-N Frequency Synthesizer with Integrated VCO in 0.18 um CMOS for RFID Systems. 2018 IEEE International Conference on Electrical Engineering and Photonics (EExPolytech). 64-68. DOI: 10.1109/EExPolytech.2018.8564373.

[24] Dunning, J., G. Garcia, J. Lundberg, and E. Nuckolls. 1995. An All-digital Phase-locked Loop with 50-cycle Lock Time Suitable for High-performance Microprocessors. IEEE J. Solid-State Circuits. 30(4): 412-422. DOI: 10.1 109/4.375961.

[25] Cheng, K.-H. and Y.-J. Chen. 2001. A Novel All Digital Phase Locked Loop (ADPLL) with Ultra Fast Locked Time and High Oscillation Frequency. Proceedings 14th Annual IEEE International ASIC/SOC Conference (IEEE Cat. No.01TH8558). 139-143. DOI: 10.1109/ASIC.2001.954687.

[26] Staszewski, R. B., J. L. Wallberg, S. Rezeq, C.-M. Hung, O. E. Eliezer, S. K. Vemulapalli, C. Fernando, K. Maggio, R. Staszewski, N. Barton, M.-C. Lee, P. Cruise, M. Entezari, K. Muhammad, and D. Leipold. 2005. All-digital PLL and Transmitter for Mobile Phones. IEEE J. Solid-State Circuits. 40(12): 2469-2482. DOI: 10.1109/JSSC.2005.857417.

[27] Staszewski, R. B., C.-M. Hung, K. Maggio, J. Wallberg, D. Leipold, and P. T. Balsara. 2004. All-digital Phase-domain TX Frequency Synthesizer for Blvetooth Radios in $0.13 \mu \mathrm{m}$ CMOS. 2004 IEEE International Solid-State Circuits Conference (IEEE Cat. No.04CH37519). 1: 272-527. DOI: 10.1109/ISSCC.2004.1332699.

[28] Chung, C.-C. and C.-Y. Lee, "An all-digital phase-locked loop for high-speed clock generation," IEEE J. Solid-State Circuits, vol. 38, no. 2, pp. 347-351, 2003, doi: $10.1109 /$ JSSC.2002.807398.

[29] Chung, C., W. Su, and C. Lo. 2016. A 0.52/1 V Fast Lock-in ADPLL for Supporting Dynamic Voltage and Frequency Scaling. IEEE Trans. Very Large Scale Integr. Syst. 24(1): 408412. DOI: 10.1109/TVLSI.2015.2407370.

[30] Chang, C. W., K. Y. Chang, Y. H. Chu, and S. J. Jou. 2016. Near-threshold all-digital PLL with Dynamic Voltage Scaling Power Management. Electron. Lett. 52(2): 109-110. DOI: 10.1049/el.2015.2672.

[31] Kuo, F.-W., S. Pourmousavian, T. Siriburanon, R. Chen, L.-C. Cho, C.-P. Jou, F.-L. Hsueh, and R.B. Staszewski. 2017. A $0.5 \mathrm{~V} 1.6 \mathrm{~mW} 2.4 \mathrm{GHz}$ fractional-N all-digital PLL for Blvetooth LE with PVT-insensitive TDC using switched-capacitor doubler in 28nm CMOS. 2017 Symposium on VLSI Circuits. C178-C179. DOI: 10.23919/VLSIC.2017.8008472.

[32] Tu, Y. H., J. C. Liu, K. H. Cheng, H. Y. Huang, and C. C. Hu. 2016. A 0.6-V 1.6-GHz 8-phase All Digital PLL using Multiphase based TDC. IEICE Electron. EXPRESS. 13(2). DOI: 10.1587/elex.12.20150950

[33] Bae, J., S. Radhapuram, I. Jo, W. Wang, T. Kihara, and T. Matsuoka. 2016. A Design of 0.7-V 400-MHz All-Digital Phase-Locked Loop for Implantable Biomedical Devices. IEICE Trans. Electron. E99.C 4: 431-439. DOI: 10.1587/transele.E99.C.431.

[34] Ho, Y., and C. Yao. 2016. A Low-Jitter Fast-Locked AllDigital Phase-Locked Loop With Phase-Frequency-Error Compensation. IEEE Trans. Very Large Scale Integr. Syst. 24(5): 1984-1992. DOI: 10.1109/TVLSI.2015.2470545.

[35] Ferreira, L., M. Moreira, B. Souza, S. Ferreira, F. Baumgratz, and S. Bampi. 2020. Review on the Evolution of Low-power and Highly-linear Time-to-Digital Converters - TDC. 2020 IEEE 11 th Latin American Symposium on Circuits \& Systems (LASCAS). 1-4. DOI: 10.1 109/LASCAS45839.2020.9068950.

[36] Balcioglu, Y. and G. Dundar. 2017. A $0.65-1.35 \mathrm{GHz}$ Synthesizable All-digital Phase Locked Loop with 
Quantization Noise Suppressing Time-to-digital Converter. TURKISH J. Electr. Eng. Comput. Sci. 25(3): 2410-2423. DOI: 10.3906/elk-1601-185.

[37] Levinger, R., E. Shumaker, R. Levi, N. Machluf, S. Levin, A. Farber, and G. Horovitz. 2019. A Compact 3.9-4.7 GHz $0.82 \mathrm{~mW}$ All-Digital PLL with 543 fs RMS Jitter in $28 \mathrm{~nm}$ CMOS. 2019 IEEE 19th Topical Meeting on Silicon Monolithic Integrated Circuits in RF Systems (SiRF). 1-4. DOI: 10.1109/SIRF.2019.8709087.

[38] Siriburanon, T., S. Kondo, K. Kimura, T. Ueno, S. Kawashima, T. Kaneko, W. Deng, M. Miyahara, K. Okada, and A. Matsuzawa. 2016. A $2.2 \mathrm{GHz}-242$ dB-FOM 4.2 mW ADC-PLL Using Digital Sub-Sampling Architecture. IEEE J. Solid-State Circuits. 51 (6): 1385-1397. DOI: 10.1 109/JSSC.2016.2546304.

[39] WU, Y., M. Shahmohammadi, Y. Chen, P. LU, and R. B. Staszewski. 2017. A 3.5-6.8-GHz Wide-Bandwidth DTCAssisted Fractional-N All-Digital PLL With a MASH DeltaSigma TDC for Low In-Band Phase Noise. IEEE J. Solid-State Circuits. 52(7): 1885-1903. DOI: 10.1 109/JSSC.2017.2682841.

[40] Liu, H., D. Tang, Z. Sun, W. Deng, H. Ngo, K. Okada, and A. Matsuzawa. 2018. A $0.98 \mathrm{~mW}$ fractional-N ADPLL using 10b Isolated Constant-slope DTC with FOM of $-246 \mathrm{~dB}$ for IOT Applications in $65 \mathrm{~nm}$ CMOS. 2018 IEEE International Solid State Circuits Conference - (ISSCC). 246-248. DOI: $10.1109 /$ ISSCC.2018.8310276.

[41] Yan, N., L. Ma, Y. XU, S. Chen, X. Liu, J. Xiang, and H. Min. 2019. A Low Power All-Digital PLL With $-40 \mathrm{dBC}$ In-Band Fractional Spur Suppression for NB-IOT Applications. IEEE Access. 7: 7897-7904. DOI: 10.1109/ACCESS.2018.2890073.

[42] Ramaswami Palaniappan, A. and L. Siek. 2019. A TDC-less all-digital Phase Locked Loop for Medical Implant Applications. Microprocess. Microsyst. 69: 168-178. DOI: https://doi.org/10.1016/j.micpro.2019.06.008.

[43] Sahani, J. K., A. Singh, and A. Agarwal. 2020. A Fast Locking and Low Jitter Hybrid ADPLL Architecture with Bang Bang PFD and PVT Calibrated Flash TDC. AEU - Int. J. Electron. Commun. 124: $153344 . \quad \mathrm{DOI}$ https://doi.org/10.1016/j.aeve.2020.153344.

[44] Dinesh, R. and R. Marimuthu. 2020. A Wide Range High Resolution Digital Controlled Oscillator with High Precision Time to Digital Convertor for Optimal Sampling Digital PLL. Microprocess. Microsyst. 74: 103013. DOI: https://doi.org/10.1016/j.micpro.2020.103013.

[45] Yang, W.-B., H.-H. Wang, H.-I. Chang, and Y.-L. Lo. 2020. A Fast-locking All-digital PLL with Dynamic Loop Gain Control and Phase Self-Alignment Mechanism for sub-GHz IOT Applications. Jpn. J. Appl. Phys. 59(SG). DOI: 10.35848/1347-4065/ab7276.

[46] Sayadi, M. and E. Farshidi. 2016. A Fast Locked and Low Phase Noise All-digital Phase Locked Loop based on Model Predictive Control. Analog Integr. Circuits Signal Process. 88(3): 401-414. DOI: 10.1007/s10470-016-0794-1.

[47] Razavi, B. 1996. A Study of Phase Noise in CMOS Oscillators. IEEE J. Solid-State Circuits. 31 (3): 331-343. DOI: $10.1109 / 4.494195$.

[48] Staszewski, R. B., D. Leipold, C.-M. Hung, and P. T. Balsara. 2002. A First Digitally-controlled Oscillator in a Deepsubmicron CMOS Process for Multi-GHz Wireless Applications. IEEE Radio Frequency Integrated Circuits (RFIC) Symposium, 2003. 81-84. DOI: $10.1109 /$ RFIC.2003.1213898

[49] XU, L., S. Lindfors, K. Stadius, and J. Ryynanen. 2010. A 2.4$\mathrm{GHz}$ Low-Power All-Digital Phase-Locked Loop. IEEE J. Solid-State Circuits. 45(8): 1513-1521. DOI: $10.1109 /$ JSSC.2010.2047453

[50] Heydarzadeh, S., P. Torkzadeh, and S. Sadughi. 2019. A Fully Linear $5.2 \mathrm{GHz}-5.8 \mathrm{GHz}$ Digitally Controlled Oscillator in 65-nm CMOS Technology. Microelectronics J. 90: 48-57. DOI: https://doi.org/10.1016/j.mejo.2019.04.018.

[51] Sadr, M. S., H. Ghafoorifard, M. Yavari, and S. Sheikhaei. 2016. A Novel Low Phase Noise and Low Power DCO in 90 $\mathrm{nm}$ CMOS Technology for ADPLL Application. 2016 24th Iranian Conference on Electrical Engineering (ICEE). 810
815. DOI: $10.1109 /$ IranianCEE.2016.7585631

[52] Haddad, F., W. Rahajandraibe, and I. Ghorbel. 2019. Compact RF CMOS 4-bit Digitally Controlled Oscillator. 2019 26th IEEE International Conference on Electronics, Circuits and Systems (ICECS). 378-381. DOI: 10.1109/ICECS46596.2019.8964931.

[53] Wang, Y., M. Wei, and R. Negra. 2019. Ultralow Power, 3.15 $\mathrm{mW}, 76.7 \mathrm{GHz}$ Digitally Controlled Oscillator in $65 \mathrm{~nm}$ CMOS for High Data-Rate Application. 2019 14th European Microwave Integrated Circuits Conference (EUMIC). 5-8. DOI: 10.23919/EUMIC.2019.8909398.

[54] Moreira, M., L. Ferreira, B. Souza, S. B. Ferreira, F. D. Baumgratz, and S. Bampi. 2019. Low Power $380 \mu \mathrm{W}$ Energy Efficient $1.8 \mathrm{GHz}$ Digitally Controlled Oscillator for IOT Applications. 2019 26th IEEE International Conference on Electronics, Circuits and Systems (ICECS). 763-766. DOi: 10.1109/ICECS46596.2019.8964984

[55] Lou, L., B. Chen, K. Tang, and Y. Zheng. 2016. A CMOS Digital-controlled Oscillator for All-digital PLL Frequency Synthesizer. 2016 International Symposium on Integrated Circuits (ISIC). 1-4. DOI: 10.1109/ISICIR.2016.7829720.

[56] Szopos, E., I. Saracut, B. S. Kirei, and M. D. Topa. 2017. Discrete Domain Modeling of an All-digital Frequency Locked Loop. 2017 International Semiconductor Conference (CAS). 247-250. DOl: 10.1109/SMICND.2017.8101214.

[57] Solanki, P., R. C. Gurjar, and D. K. Mishra. 2018. Design of LC-Tank Digitally Controlled Oscillator with Variable Capacitor. 2018 4th International Conference for Convergence in Technology (I2CT). 1-4. DOI: 10.1109/I2CT42659.2018.9058250.

[58] Suraparaju, E. R., P. V. R. Arja, and S. Ren. 2015. A 1.1-8.2 $\mathrm{GHz}$ tuning Range In-phase and Quadrature Output DCO design in $90 \mathrm{~nm}$ CMOS Technology. 2015 IEEE 58th International Midwest Symposium on Circuits and Systems (MWSCAS). 1-4. DOI: 10.1 109/MWSCAS.2015.7282171.

[59] Dabas, S. and M. Kumar. 2016. A New Design of Digitally Controlled Oscillator for Low Power Applications. 2016 2nd International Conference on Contemporary Computing and Informatics (IC3I). 671-675. DOI: 10.1109/IC31.2016.7918047.

[60] Pahlavan, S. and M. B. Ghaznavi-Ghoushchi. 2016. $1.45 \mathrm{GHz}$ Differential Dual Band Ring based Digitallycontrolled Oscillator with a reconfigurable Delay Element in $0.18 \mu \mathrm{m}$ CMOS Process. Analog Integr. Circuits Signal Process. 89(2): 461-467. DOI: 10.1007/s10470-016-0814-1.

[61] Yuan, C., and S. Shekhar. 2019. A Supply-Noise-Insensitive Digitally-Controlled Oscillator. IEEE Trans. Circuits Syst. I Regul. Pap. 66(9): 3414-3422. DOl: 10.1109/TCSI.2019.2924399

[62] Sheng, D., W.-Y. Chen, Y.-H. Chang, and H.-T. Huang. 2020. High-Timing-Resolution and Low-Complexity CellBased Digitally Controlled Oscillator. 2020 IEEE International Conference on Consumer Electronics Taiwan (ICCE-Taiwan). 1-2. DOI: 10.1109/ICCETaiwan49838.2020.9258210.

[63] Bisiaux, P., E. Blokhina, E. Koskin, T. Siriburanon, and D. Galayko. 2020. Design of a $1.5 \mathrm{GHz}$ Low jitter DCO Ring in 28 nm CMOS Process. 2020 European Conference on Circuit Theory and Design (ECCTD). 1-5. DOI: 10.1109/ECCTD49232.2020.9218352.

[64] Selvaraj, S., E. Bayram, and R. Negra. 2020. Low Phase Noise, High Resolution Digitally-controlled Ring Oscillator Operating at $2.2 \mathrm{GHz}$. DOI: 10.1109/MOCAST49295.2020.9200.272

[65] Dabas, S. and M. Kumar. 2019. A CMOS based Low Power Digitally Controlled Oscillator Design with MOS Varactor. Analog Integr. Circuits Signal Process. 100(3): 565-575. DOI: 10.1007/s10470-019-01476-0.

[66] Bai, J., J. Lee, J. Zhang, and N. Rohani. 2017. A 28-nm CMOS 40-GHz High-resolution Digitally Controlled Oscillator for Automotive Radar Applications. 2017 IEEE 17th Topical Meeting on Silicon Monolithic Integrated 
Circuits in RF Systems (SiRF). 91-93. DOI: 10.1109/SIRF.2017.7874380.

[67] Yagi, M., K. Komoku, T. Morishita, and N. Itoh. 2019. A Study on 14 bit Digital Controlled Oscillator Using Switched
Striped Inductor. 2019 IEEE Asia-Pacific Microwave Conference (APMC).

10.1109/APMC46564.2019.9038716. 